Oza, Premlata \& Oza, Gunavant M. (1994). Every day a Biosphere Day: path for sustainability. Environmental Conservation, 21(2), pp. 174-6, 4 figs.

OzA, G.M. \& Polunin, N. (1988). Fond tribute to an ardent conservationist: H.H. Fatehsinghrao P. Gaekwad, 1930-88. Environmental Conservation, 15(3), pp. 271-2, fig.

Premlata Oza,

Joint Secretary of INSONA \& Managing Editor of Environmental Awareness;

Trustee of the Foundation for

Environmental Awareness,
$\&$

Gunavant M. Oza, President

The Foundation for Environmental Awareness, General Secretary of INSONA, and Founding Editor of Environmental Awareness Oza Building

Salatwada

Baroda 390001

India.

\title{
Canadian Arrest of Spanish Fishing Vessel for Conservation Violations
}

$\mathrm{O}^{\mathrm{n}}$ 9 March 1995 Canadian authorities arrested the Spanish fishing trawler, Estai. Inspection by Canadian authorities has revealed that the Estai was engaged in serious violations of the most elementary conservation rules:

- false log-books (for catch and production);

- misreporting of catch (volume and species);

- systematic catching of immature fish; and

- systematic use of nets with small mesh-size (catching immature fish).

Two sets of catch and production log-books have been found: one set contains actual catch and production records; the second contains false information designed to disguise the amount and composition of the catch on board.

The captain's personal log has been found and is significantly different from the log used to report to NAFO [Northwest Atlantic Fishing Organization]. The captain over-reported Greenland Halibut (Reinhardtius hippoglossoides, also called Turbot) catches in December 1994 when no NAFO quotas were in place, to cover planned over-fishing of Greenland Halibut in January 1995. The vessel under-reported catches in January since catches in 1995 became subject to NAFO quotas. Beginning in January, the captain also misreported Greenland Halibut as Skate (presumably Raja erinacea), a species not currently regulated by NAFO.

Inspection of the vessel has established that it contained 350 tonnes of Greenland Halibut. The average length of a mature fish of this species - ones that can reproduce and sustain the fishery - is $60-70 \mathrm{~cm}$. None of the fish found on board the Estai are of a size capable of reproduction. Six per cent of the catch by weight was less than $17 \mathrm{~cm}$ in length. This is significant ecologically as the number of individuals per tonne that are removed from their ecosystem will of course be greater, the smaller the size of the fish.

At the time of inspecting the Estai's catch, the size composition of the fish strongly suggested the systematic use of nets of a small mesh-size in violation of NAFO rules. Canadian authorities undertook a successful search (by dragging) for the Estai's net, which had been cut loose by the ship's crew when it attempted to flee from Canadian enforcement authorities. The size of the mesh was $115 \mathrm{~mm}$, i.e. smaller than the $130 \mathrm{~mm}$ permitted by NAFO. Furthermore, the net had a liner with an $80 \mathrm{~mm}$ mesh which would account for the fact that the catch on board comprised a large percentage of immature fish.

The fact that not a single mature Greenland Halibut has been found on board the Estai reinforces Canada's conservation concerns about the irresponsible conduct of this fishery by the Spanish fleet and the need to develop agreed enforceable conservation and management practices.

Canada continues to urge the European Union to adhere to the 60 days' moratorium on fishing in the NAFO area which is also being applied to Canadian fishermen both inside and outside the 200 miles economic zone, and to negotiate a solution, so that yet other over-fishing tragedies such as this one which is now being fully revealed in the Northwest Atlantic, can be avoided.*

\section{Canadian Permanent Mission TO THE UNITEd Nations IN GENEVA 1 Pré-de-la-Bichette 1202 Geneva, Switzerland.}

* For a suggested future solution see page 3 of this issue which by chance was drafted before the above controversy started and reemphasized the absolute need to consider matters globally rather than selfishly, the ultimate right to our mind being that which is best for The Biosphere. - Ed.

\section{Enforcement of Environmental Laws and Regulations}

$\mathrm{E}^{\mathrm{n}}$ nforcement of environmental laws and regulations in their true spirit in most developing countries has simply become ironical. With corruption and malpractices assuming monstrous proportons, industries are jeopardizing our environment. One of the most glaring examples in the recent past of environmental lapse and mismanagement has been the Bhopal gas leak disaster, in which thousands were killed and many more injured and maimed for life through no fault of their own. Even today there are factories, large and small industries, ancillaries, and in-house units in developing countries, which grossly violate the laws, if not on paper then at least environmentally.

In the Indian capital, Delhi, a day on the city's roads is as bad as smoking 20 cigarettes, making a third of the city's residents suffer from respiratory ailments. Water, when not scarce, is often contaminated. Despite lots of funds, publichealth laboratories, mobile monitoring units, and a battery of employees, there is no proper data-collection and -interpretation, and as a result drinking-water units are full of germs, parasites, and other contaminants. Rivers which were once lifelines have become full of sewage and cause endemic diseases which take a heavy toll.

Recently, a pesticide factory in Bhopal even got the President's Award for Environmental Protection and Safety, though its workers were found to suffer from several toxicological manifestations. We found that they worked in the pesticide factory for more than eight hours under extremely adverse and even unsafe conditions. Two-thirds of the workers complained of severe neurological, haematological, or other problems, associated with highly elevated cholinesterase levels (S.A. Khan \& S.A. Ali [1993], Bull. Environ. Cont. Toxicol., 51(5), pp. 740-7; S.A. Khan [1991], PhD thesis, Bhopal University, Bhopal, India). Cannot we do something to remove this strange paradox?

Perhaps if international agencies such as WHO, IUCN, UNEP, GREENPEACE, and Worldwatch Institute, step in and set up autonomous environmental monitoring cells at strategic places in poor developing nations, the malady can 